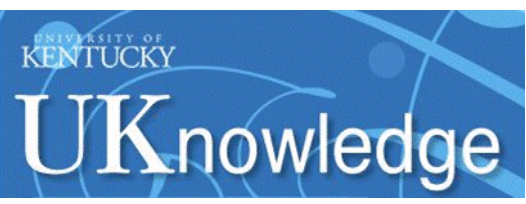

University of Kentucky

UKnowledge

\title{
The Old and the New Eastern State Hospital in Lexington, Kentucky
}

Jose de Leon

University of Kentucky, jdeleon@uky.edu

Shane Shoemaker

University of Kentucky

Allen Brenzel

University of Kentucky, allen.brenzel@uky.edu

Follow this and additional works at: https://uknowledge.uky.edu/psychiatry_facpub

Part of the Psychiatry and Psychology Commons

Right click to open a feedback form in a new tab to let us know how this document benefits you.

\section{Repository Citation}

de Leon, Jose; Shoemaker, Shane; and Brenzel, Allen, "The Old and the New Eastern State Hospital in Lexington, Kentucky" (2014). Psychiatry Faculty Publications. 21.

https://uknowledge.uky.edu/psychiatry_facpub/21

This Article is brought to you for free and open access by the Psychiatry at UKnowledge. It has been accepted for inclusion in Psychiatry Faculty Publications by an authorized administrator of UKnowledge. For more information, please contact UKnowledge@lsv.uky.edu. 


\section{The Old and the New Eastern State Hospital in Lexington, Kentucky}

Digital Object Identifier (DOI)

http://dx.doi.org/10.1176/appi.ajp.2013.13070959

\section{Notes/Citation Information}

Published in The American Journal of Psychiatry, v. 171, issue 2, p. 149-150.

Copyright ( American Psychiatric Association. All rights reserved.

The copyright holder has granted the permission for posting the article here.

The document available for download is the authors' post-peer-review final draft of the article. 


\section{THE AMERICAN JOURNAL OF \\ PSYCHIATRY}

\section{The Old and the New Eastern State Hospital in Lexington, Kentucky}

\begin{tabular}{|r|l|}
\hline Journal: & The American Journal of Psychiatry \\
\hline Manuscript ID: & AJP-13-07-0959.R1 \\
\hline Manuscript Type: & Image in Psychiatry \\
\hline Date Submitted by the Author: & n/a \\
\hline Keywlete List of Authors: & $\begin{array}{l}\text { de Leon, Jose; EASTERN ST HOSP, MTL HLTH RESEARCH CTR; } \\
\text { Shoemaker, Shane; Eastern State Hospital, } \\
\text { Brenzel, Allen; Unversity of Kentucky, Psychiatry }\end{array}$ \\
\hline & History Of Psychiatry - AJP0143, Inpatient Psychiatry - AJP0129 \\
\hline
\end{tabular}


Word count: 375 words in text

\section{The Old and the New Eastern State Hospital in Lexington, Kentucky}

Jose de Leon, M.D.; Shane Shoemaker, M.L.S.; Allen Brenzel, M.D., MBA

\section{Affiliations:}

Dr. de Leon: Department of Psychiatry, University of Kentucky, Lexington, KY, USA; and Eastern State Hospital, Lexington, KY, USA.

Mr. Shoemaker: Eastern State Hospital, Lexington, KY, USA

Dr. Brenzel: Department of Psychiatry, University of Kentucky, Lexington, KY, USA;

Eastern State Hospital, Lexington, KY, USA; and Department of Behavioral Health, Developmental and Intellectual Disabilities, Frankfort, KY, USA.

\section{Location of work and address for reprints:}

Jose de Leon, M.D., UK Mental Health Research Center at Eastern State Hospital, 627 West

Fourth St., Lexington, KY 40508; Phone (859) 246-7563; Fax (859) 246-7019;

E-mail: jdeleon@uky.edu

Disclosures: No commercial organizations had any role in the writing of this paper for publication.

Acknowledgments: The picture of the old hospital is no longer subject to copyright law (it was originally published in a book in $1872^{1}$ ) and is reproduced courtesy of the Lexington Public Library, Lexington, Kentucky. The picture of the new hospital is from Mr. Shoemaker's archive; he holds the copyright. The authors thank Lorraine Maw, M.A., and Margaret T. Susce, R.N., M.L.T., for editorial assistance. 


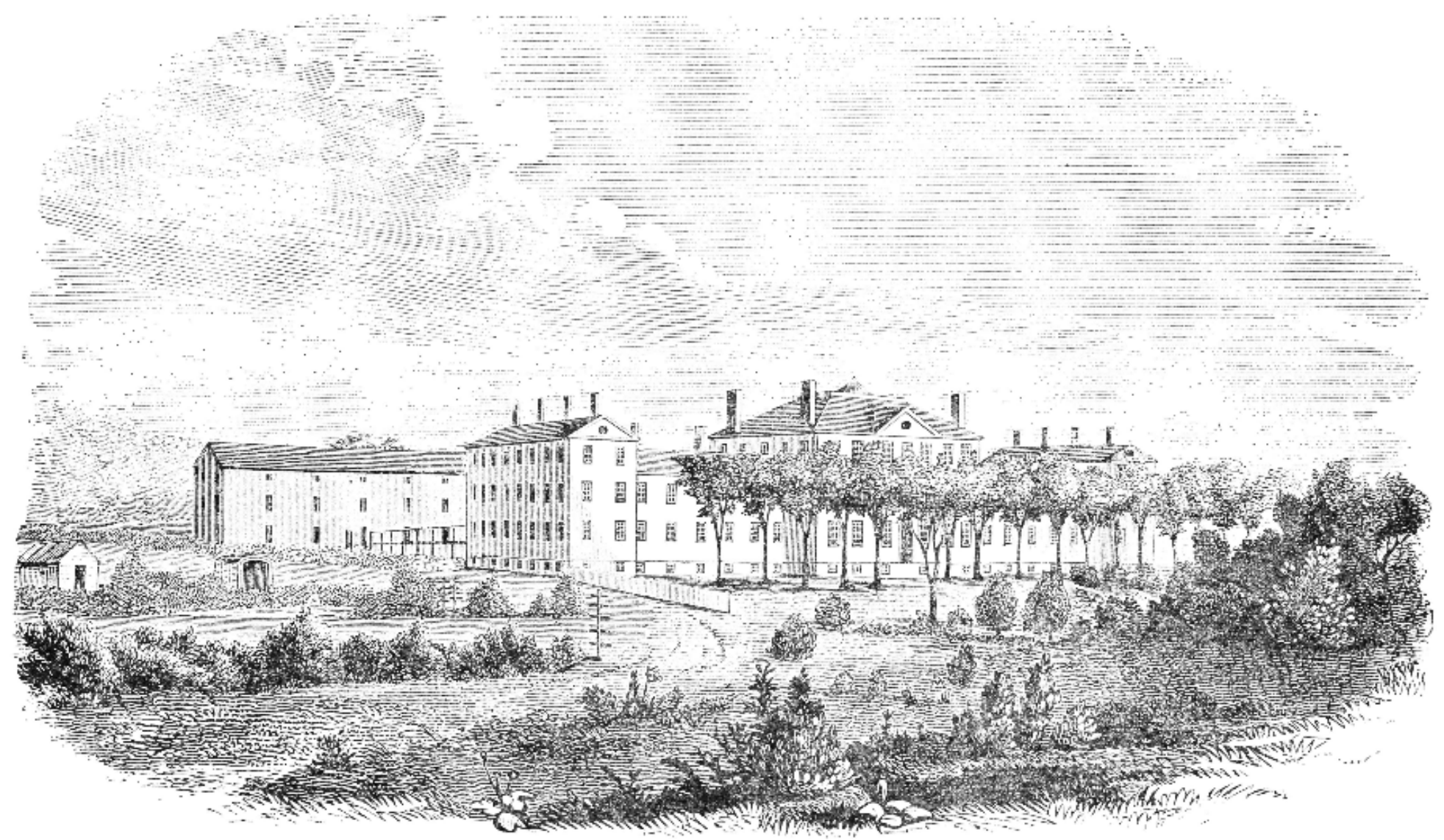

FASTHRN IUNATIC ASYLUM, I.HXINGTON, KY, TN $3 B_{46}$

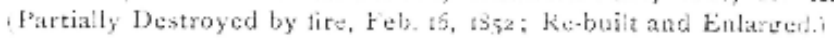




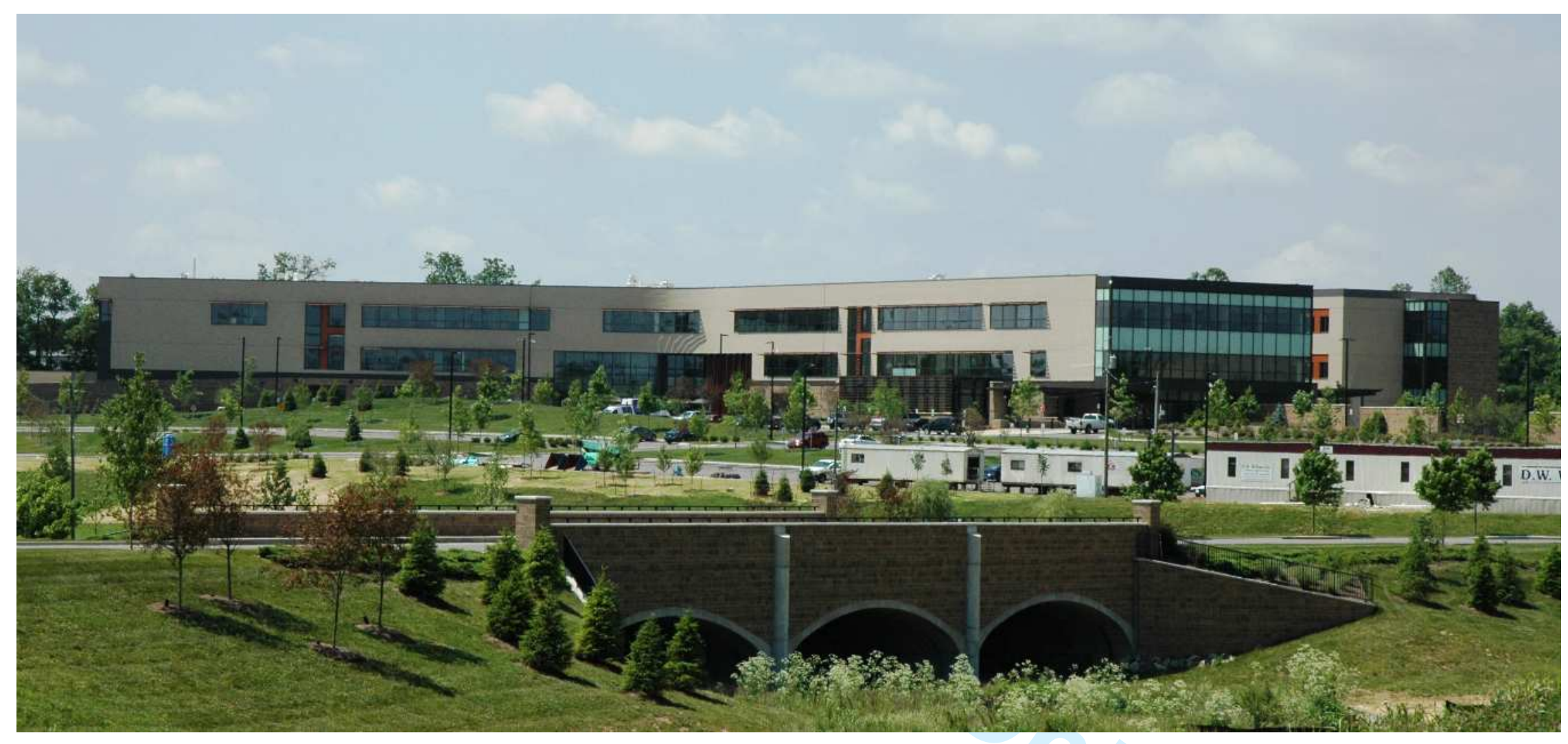


In 1766 the first US public psychiatric hospital, Eastern State Hospital, was opened in Williamsburg, Virginia. Another Eastern State Hospital (Figure 1) has continuously functioned in Lexington, Kentucky, since 1824. After nearly two centuries, a new a state-of-the-art patientcentered hospital (Figure 2) will open this fall.

In the late 1700s, Kentuckians who developed severe mental illness were sent to Williamsburg. In 1816, a group of public-spirited citizens in Lexington planned for a hospital for the poor, disabled and "lunatic" members of society. In 1822, the General Assembly of the Commonwealth of Kentucky passed an "Act to Establish a Lunatic Asylum”. Ten acres of land, along with the unfinished hospital building, were purchased and thus the second oldest state mental hospital in the US was established. ${ }^{1}$ After the opening in 1824, the name changed several times, but become Eastern State Hospital in 1912.

Lexington's Eastern State Hospital included a 400-acre farm and was an isolated institution, separate from the surrounding community. Many employees lived on the grounds in cottages, dormitories, separate rooms in the main hospital building, or on wards with the residents. The hospital residents and staff grew and prepared most of the food consumed. A dedicated train station provided the remaining food, supplies and coal for the on-site boilers. In 1956, over 300 acres of the farm were sold to IBM and later became Lexmark. As late as 1967, the hospital had 1000 patients in residence. In the 1990s, the few remaining long-term patients were progressively discharged and the hospital became solely an acute psychiatric hospital, serving 1600-2000 admissions/year from a catchment area in central and northern Kentucky. In 1995, the state asked the Bluegrass Regional Mental Health/Mental Retardation Board, which was operating community mental health centers, to run the hospital as well. 
Page 5 of 5

The American Journal of Psychiatry

5

Lexington's third century of public psychiatric care will begin in a scenic new location less than a mile from the original location. A land swap was proposed in 2008 among the state, Bluegrass Community and Technical College (BCTC), and the University of Kentucky (UK).

The old Eastern State Hospital grounds, including the administration building, are being transferred to BCTC. The main administrative building and a laundry building will be preserved. UK provided the 30-acre new site to build the new hospital. References

1. Collins L. History of Kentucky. Volume II. Frankfort, KY, Kentucky Historical Society, 1966. 